\title{
Adult-type hypolactasia and lactose malabsorption in Poland
}

\author{
Edyta Mądry' ${ }^{1}$ Aleksandra Lisowska², Jarosław Kwiecień ${ }^{3}$, Ryszard Marciniak ${ }^{4}$ Anna Korzon- \\ Burakowska5 ${ }^{5}$ 2Sławomira Drzymała-Czyż², Ewa Mojs ${ }^{6}$ and Jarosław Walkowiak²,7凶
}

1Department of Physiology, Poznań University of Medical Sciences, Poznań, Poland; and 2Department of Pediatric Gastroenterology \& Metabo-

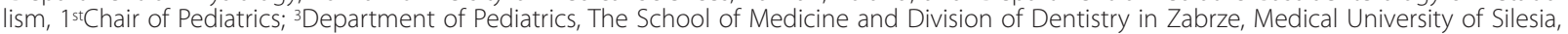
Katowice, Poland; ' ${ }^{C}$ Chair of General, Gastroenterological and Endocrinological Surgery, Poznań University of Medical Sciences, Poznań, Poland; ${ }^{5}$ Department of Hypertension and Diabetology, Medical University of Gdańsk, Poland; ${ }^{6}$ Clinical Psychology Department, Poznań University of Medical Sciences, Poznań, Poland; 'Department of Dietetics, Chair of Human Nutrition \& Hygiene, Poznan University of Life Sciences, Poznań, Poland

Background: The available data on the incidence of lactose malabsorption are contradictory. Potential bias in random selection is a major drawback of studies performed to-date. Moreover, molecular analysis of polymorphism $-13910 \mathrm{C}>\mathrm{T}$ upstream of the lactase (LCT) gene (NM_005915.4:C.1917+326C>T; rs4988235) has not been reported in those studies. Therefore, in this study we aimed to assess genetic predisposition and clinical manifestation of adult-type hypolactasia (ATH). Patients and methods: In two-hundred randomly chosen healthy subjects (HS) aged from 18 to 20 years, the presence of $-13910 \mathrm{C}>\mathrm{T}$ polymorphic variants upstream of the $L C T$ gene was assessed. In a subgroup of subjects with genotype predisposing to ATH, hydrogen-methane breath test (BT) with lactose loading was conducted to determine the current state of lactase activity. In addition, clinical symptoms typical for lactose malabsorption were assessed using the questionnaire method. Results: Sixtythree out of 200 (31.5\%) HS had -13910 C/C genotype. Thus, genetically determined lactase persistence is expected in the remaining $137(68.5 \%)$ subjects. Thirteen out of $53(24.5 \%)$ HS having $-13910 \mathrm{C} / \mathrm{C}$ genotype were proved to be lactose intolerant. Recalculating the data for the entire studied population it implies the incidence of lactose malabsorption in $7.7 \%$ of subjects. Only three out of $13(23.1 \%)$ subjects with abnormal BT results, reported clinical symptoms related to lactose consumption. Conclusions: Significantly lower than previously reported incidence of clinically detectable lactose malabsorption in young healthy adults in Poland has been documented. The $-13910 \mathrm{C} / \mathrm{C}$ genotype upstream of the LCT gene indicates a predisposition to ATH, but definitely does not define the current ability to tolerate lactose.

Keywords: hypolactasia, lactose malabsorption, lactose intolerance, genetic predisposition

Received: 02 August, 2010; revised: 20 October, 2010; accepted: 09 November, 2010; available on-line: 10 December, 2010

\section{BACKGROUND}

Lactase (LCT) is an enzyme of small intestine brush border that breaks down lactose into two monosugars: glucose and galactose. The production of LCT is dependent on the expression of the lactase-phlorizin hydrolase gene (LCT). Lactose malabsorption (LM) occurs due to a deficiency in the LCT activity (hypolactasia) (Ingram et al., 2009). The symptoms of lac- tose intolerance (diarrhea, abdominal pain, flatulence, bloating, cramps) (Heyman, 2006) result from bacterial fermentation of undigested lactose in the colon and may result in avoidance of dairy products by afflicted individuals (Di Stefano et al., 2006). This condition is apparently the major reason for avoiding milk products worldwide (Scrimshaw et al., 1988; Vesa et al., 1996; Savaiano et al., 2006). Insufficient vitamin $\mathrm{D}$ and calcium intake associated with the restricted intake of milk and dairy products can lead to poor health outcomes, particularly related to bone mineral density and risk of fractures (Di Stefano et al., 2001; Enattah et al., 2005).

Several single nucleotide polymorphisms (SNP) were described upstream of the LCT gene and the surrounding regions (Järvelä et al., 1998; Enattah et al., 2002; 2008). It was reported that homozygous genotype of allelic variant C at position 13910 (C13910) upstream of the LCT gene is tightly associated with adult-type of hypolactasia (ATH) (Enattah et al., 2002). The homoor heterozygous genotype of T13910 variant upstream of the LCT gene results in lactase persistence. ATH is the most common cause of milk intolerance in children, adolescents and adults and the most common enzyme deficiency in humans (Semenza, 2001). Clinically, it results in lactose intolerance. The incidence of ATH is ethnic-dependent, highly varied (3-100\%) (Hollox et al., 2001; Ingram et al., 2009) and difficult to discern because studies differ both in terms of applied methodology and data interpretation. Two relatively large studies performed in Poland have provided contradictory results on the incidence of lactose malabsorption $(17.4 \%$ vs. $37.5 \%)$ as assessed with the use of hydrogen breath test (Socha et al., 1984; Kwiecień et al., 2005). No molecular analysis of SNP upstream of the LCT gene has been conducted in them. Potential bias in random selection is a major drawback of both studies. Moreover, the ATH incidence obtained in the first study is higher than expected for Central and Eastern Europe (Socha et al., 1984). Therefore, in the present study we aimed to assess genetic predisposition and clinical manifestation of ATH with the use of modern and reliable tools.

e-mail: edytamadry@poczta.onet.pl

Abbreviations: ATH, adult-type hypolactasia; HS, healthy subjects; $B T$, hydrogen-methane breath test; $L C T$, lactase gene; LCT, lactase; $\mathrm{LI}$, lactose intolerance; LM, lactose malabsorption; SNP, single nucleotide polymorphisms 


\section{PATIENTS AND METHODS}

The survey was carried out in the years 2006-2009. Two-hundred of randomly chosen healthy subjects of Polish origin (HS; 98 females and 102 males) aged from 18 to 20 years entered the study. Entire students' groups were included under the condition of at least $95 \%$ participation. In all subjects, peripheral blood was drawn and total genomic DNA was extracted from fresh or frozen blood. The kit MutaGEL Lactase (Immundiagnostik AG, Bensheim, Germany) was used for detection of the $-13910 \mathrm{~T}>\mathrm{C}$ polymorphism upstream of the LCT gene (NM_005915.4:c.1917+326C>T; rs4988235) by direct allele-specific detection of genotype.

The DNA concentration and level of protein contamination were determined from absorbance at $260 \mathrm{~nm}$ and $280 \mathrm{~nm}$. An $\mathrm{A}_{260} / \mathrm{A}_{280}$ ratio $\geq 1.8$ indicates high purity of DNA. Such material was amplified by PCR with two sets of primers allel-specific for the lactase gene. Amplified DNA fragments were separated by electrophoresis in agars' gel and visualized by ethidium bromide staining. The presence of "C"'-base was indicated by detection of DNA product (170 bp) in MIX 1 ("Primer C"), whereas the presence of "T"-base was indicated by detection of DNA product (170 bp) in MIX 2 ("Primer T"). Internal control fragment for PCR was detected at $400 \mathrm{bp}$.

In 53 subjects with $-13910 \mathrm{C} / \mathrm{C}$ genotype upstream of LCT gene, hydrogen-methane breath test (BT) with lactose loading was conducted to determine the current state of lactase activity. BT was performed after overnight fasting. Patients were instructed not to eat or drink for at least $12 \mathrm{~h}$ before the test and to avoid slowly digesting foods such as beans and similar vegetables, brans or high-fiber cereals the day before the test. Subjects were not allowed to smoke, sleep or exercise vigorously for at last $1 \mathrm{~h}$ before or at any time during the test. Every patient received lactose dissolved in water orally in a dose of $25 \mathrm{~g}$. Breath samples were collected at baseline (fasting) and at 30,60, 90, 120, 150 and 180 min after lactose ingestion. The samples were analyzed with a QuinTron MicroLyser DP Plus (Quintron, USA). A positive BT was defined as breath $\mathrm{H}_{2}$ level increase of at least $20 \mathrm{ppm}$ over the lowest preceding value within the test period or breath $\mathrm{CH}_{4}$ level increase of at least $12 \mathrm{ppm}$ over the baseline within the test period or combined increase of at least 15 ppm within the test period.

Clinical symptoms were assessed using a questionnaire. The following issues were addressed: 1/ drinking milk or ingesting other dairy products (at all, irregular or regular), 2/ symptoms after ingestion of dairy products (abdominal pain, flatulence, bloating, cramps, diarrhea).

The protocol of the investigation was approved by the Bioethical Committee of the Poznań University of Medical Sciences (Poland).

\section{RESULTS}

The distribution of SNP allelic variants upstream of the LCT gene in $200 \mathrm{HS}$ in the studied group is presented in Fig. 1. Sixty-three out of $200(31.5 \%)$ HS had genotype predisposing to ATH. Thus, genetically determined lactase persistence is expected in the remaining $137(68.5 \%)$ subjects.

Thirteen out of 53 (24.5\%) HS having $-13910 \mathrm{C} / \mathrm{C}$ genotype were proved to be lactose malabsorbers on the basis of BT (Fig. 2). Recalculating the data for the entire population it implies the incidence of lactose malabsorp-

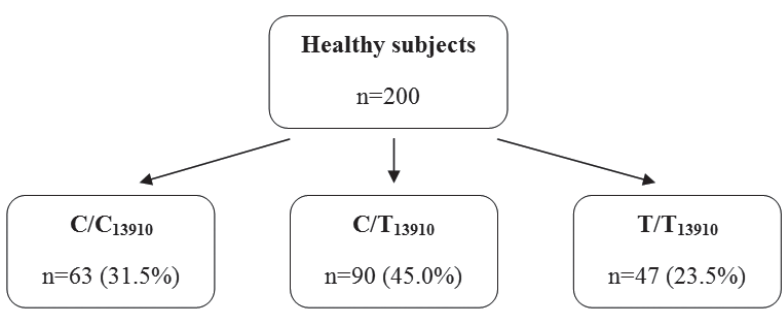

Figure 1. Distribution of $-13910 \mathrm{C}>\mathrm{T}$ genotypes upstream of lactase gene

tion in $7.7 \%$ of subjects. Only three out of $13(23.1 \%)$ subjects with abnormal BT results reported clinical symptoms related to lactose consumption.

\section{DISCUSSION}

The incidence of lactose malabsorption in Polish children aged 8-11 years and adolescents/adults in a wide range of age (16-59 years) was estimated to be $17.4 \%$ and $37.5 \%$, respectively (Socha et al., 1984; Kwiecień et al., 2005). The observed difference between these studies is substantial, with the frequency of LM in the latter one being higher than expected for Central and Eastern Europe. A truly random selection of the studied subjects is doubtful, especially in the second study. "Free" volunteering may result in a significant bias, promoting the recruitment of subjects with ATH. Therefore, in the present study we included entire students' groups under condition of at least $95 \%$ participation. Interestingly, we documented a substantially lower incidence of lactose malabsorption $(7.7 \%)$ in the studied population. The large divergence between our results and previous data may be also explained by other methodological issues. BT was performed in both studies cited above on the basis of a protocol with a $50 \mathrm{-g}$ dose of lactose (Socha et al., 1984; Kwiecień et al., 2005). This methodology was suggested to provide low accuracy with many false positive results (Strocchi et al., 1993). We used a more reasonable amount of $25 \mathrm{~g}$ of lactose that is equivalent to 0.51 of milk. Moreover, we used hydrogen-methane instead of hydrogen breath test which allows to exclude some potential false negative results (Lisowska et al., 2009).

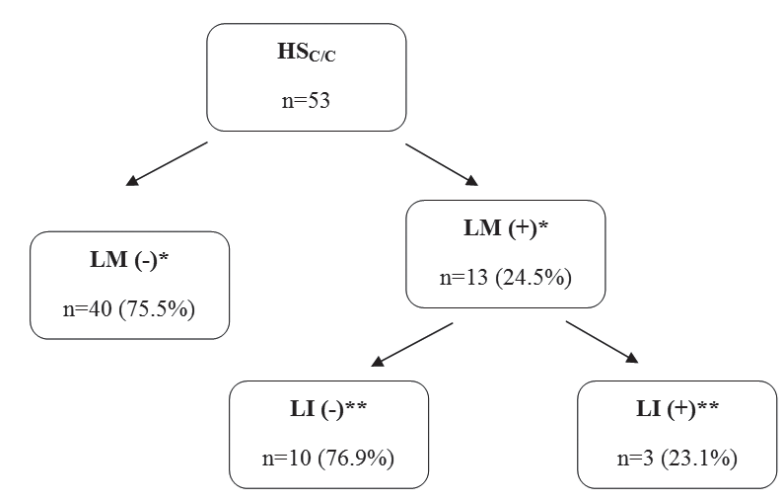

* LM $(-)=$ negative breath test; $\mathrm{LM}(+)=$ positive breath test

** LI $(-)=$ lack of symptoms; LI $(+)=$ symptoms present

Figure 2. Prevalence of lactose malabsorption (LM) and lactose intolerance (LI) in 53 healthy subjects having $-13910 \mathrm{C} / \mathrm{C}$ genotype upstream of lactase gene $\left(\mathrm{HS}_{\mathrm{C} / \mathrm{C}}\right)$ 
The SNP analysis of $-13910 \mathrm{C}>\mathrm{T}$ variants upstream of the LCT gene created a reliable background for ATH detection and confirmation (Rasinperä et al., 2004; Enattah et al., 2007). The frequency of $-13910 \mathrm{C} / \mathrm{C}$ genotype $(31.5 \%)$ in the present study approximates the upper limit of ATH incidence in the Polish population. Interestingly, only $24.5 \%$ of subjects with genetic predisposition to ATH demonstrated lactose malabsorption in BT. This indicates that most of the young adult subjects with $-13910 \mathrm{C} / \mathrm{C}$ genotype were still able to tolerate lactose and could consume milk and dairy products without major restrictions. The data here may potentially question the reliability of genetic testing. As documented by Rasinperä et al. (2004) and Enattah et al. (2007), molecular analysis supplies reliable and useful diagnostic data. It provides information about the intestinal lactase expression genotype, while BT indicates the actual presence of lactose malabsorption (Di Stefano et al., 2006; Mądry et al., 2010).

In order to be lactose tolerant it is sufficient to have one active LCT allele. It has been demonstrated by two independent studies that the majority of lactase mRNA present in lactase tolerant heterozygous individuals originates from only one allele consistent with their heterozygous status (Boll et al., 1991; Swallow, 2003). This result is highly informative because it clearly demonstrates that ATH is caused by cis-acting transcriptional silencing of the LCT gene and that the individual lactase alleles are regulated independently (Wang et al., 1995). Lactase activity lowering is a process that takes place progressively over time; in most mammals lactase activity is high at birth and during breast-feeding, then declines at weaning to low adult levels (Newcomer, 1966). This physiological dependence makes the prevalence of lactose malabsorption in subjects with $-13910 \mathrm{C} / \mathrm{C}$ genotype increase significantly with age (Di Stefano et al., 2001). According to Krawczyk et al. (2008) the concordance between genetic test and BT is excellent $(100 \%)$. Nevertheless, the median age in the studied group was 41 years and patients were admitted to the hospital for symptoms suggesting lactose intolerance (Krawczyk et al., 2008). The age of ATH onset shows a wide ethnic and regional variation. The majority of Black and Asian populations have been demonstrated to become hypolactasic in early childhood, whereas in Caucasians a low lactase level is rarely seen in children under five years of age. LM related to ATH seems to occur later in childhood or in adolescence (Scrimshaw \& Murray, 1988). There is some evidence that intestinal lactase activity does not continue to decline with age, because no differences in the prevalence of lactose malabsorption were found between older and younger adults (Jussila et al., 1970). However, its prevalence is more common in adults than in children (Caskey et al., 1977; Welsh et al., 1978). We have documented in the present study a quite low incidence $(24.5 \%)$ of lactose malabsorption in genetically predisposed young healthy adults, which may suggest later silencing of $L C T$ gene in the Polish population. We may assume with very high probability that the $-13910 \mathrm{C} / \mathrm{C}$ genotype indicates a predisposition to ATH, but definitely does not determine the current clinical status which can be identified by BT.

Interestingly, only $23.1 \%$ of subjects with abnormal BT results reported clinical symptoms related to diary product consumption. Therefore, exclusively symptomatic screening for subjects with ATH seems to have limited value as it was also documented by Sahi (1978). Jussila et al. (1970) reported that the mean age of symp- tomatic lactose intolerant subjects was higher (46 years) than that of non-symptomatic lactose maldigesters (31 years), whereas Suarez and Savaiano (1994) indicated no difference in the symptoms between the age groups of over 65 years and 20 to 40 years. It is possible that the subjects in the latter study were specially selected, since they were recruited by announcements in certain neighborhoods. Moreover, the number of subjects may be not sufficient to draw definitive conclusions (20 people in each of two groups).

The lack of a uniform study design and methodology hampers a rational, evidence-based approach to diagnosis and management of lactose intolerance. It seems important to draw attention at least to a uniform nomenclature. This will contribute to easier comparisons between different studies and can be helpful in conducting metaanalyses. The $-13910 \mathrm{C} / \mathrm{C}$ genotype points to genetic predisposition to ATH. Positive BT is equivalent to lactose malabsorption. The presence of clinical symptoms should be defined as lactose intolerance.

In conclusion, the results from this study show a lower incidence of clinically detectable lactose malabsorption $(7.7 \%)$ in young healthy adults in Poland than it was reported previously. The $-13910 \mathrm{C} / \mathrm{C}$ genotype $(31.5 \%)$ indicates a predisposition to ATH, but definitely not the current clinical status. We would like to emphasize a clinical utility of both tests (molecular analysis and BT) and their complementary role as well as to stress the importance of additional investigation to provide evidence-based and culturally sensitive data about ATH and silencing lactase activity with age.

\section{Acknowledgements}

We thank Nigel Biswas-Baldwin for his valuable comments and language correction.

Supported by the Ministry of Science and Higher Education, Poland (grant No. N407 2110 33) and Poznań University of Medical Sciences (University grant).

\section{REFERENCES}

Boll W, Wagner P, Mantei N (1991) Structure of the chromosomal gene and cDNAs coding for lactase-phlorizin hydrolase in humans with adult-type hypolactasia or persistence of lactase. Am J Hum Genet 48: 889-902.

Caskey DA, Payne-Bose D, Welsh JD, Gearhart HL, Nance MK, Morrison RD (1977) Effects of age on lactose malabsorption in Oklahoma native Americans as determined by breath $\mathrm{H} 2$ analysis. Dig Dis 22: 113-116.

Di Stefano M, Veneto G, Malservisi S, Strocchi A, Corazza GR (2001) Lactose malabsorption and intolerance in the elderly. Scand J Gastroenterol 36:1274-1278.

Di Stefano M, Veneto G, Malservisi S, Cecchetti L, Minguzzi L, Strocchi A, Corazza GR (2002) Lactose malabsorption and intolerance and peak bone mass. Gastroenterology 122: 1793-1799.

Di Stefano M, Miceli E, Missanelli A, Mazzocchi S, Tana P, Corazza GR (2006a) Role of colonic fermentation in the perception of colonic distention in irritable bowel syndrome and functional bloating. Clin Gastroenterol Hepatol 4: 1242-1247.

Di Stefano M, Miceli E, Missanelli A, Mazzocchi S, Tana P, Corazza GR (2006b) Role of colonic fermentation in the perception of colonic distention in irritable bowel syndrome and functional bloating. Clin Gastroenterol Hepatol 4: 1242-1247.

Enattah NS, Sahi T, Savilahti E, Terwilliger JD, Peltonen L, Järvelä I (2002) Identification of a variant associated with adult-type hypolactasia. Nat Genet 30: 233-237.

Enattah NS, Sulkava R, Halonen P, Kontula K, Järvelä I (2005) Genetic variant of lactase-persistent $\mathrm{C} / \mathrm{T}-13910$ is associated with bone fractures in very old age. I Am Geriatr Soc 53: 79-82.

Enattah NS, Kuokkanen M, Forsblom C, Natah S, Oksanen A, Jarvela I, Peltonen L, Savilahti E (2007) Correlation of intestinal disaccharidase activities with the C/T-13910 variant and age. World J Gastroenterol 13: 3508-3512. 
Enattah NS, Jensen TG, Nielsen M, Lewinski R, Kuokkanen M, Rasinpera $\mathrm{H}$, El-Shanti $\mathrm{H}$, Seo JK, Alifrangis M, Khalil IF, Natah A, Ali A, Natah S, Comas D, Mehdi SQ, Groop L, Vestergaard EM, Imtiaz F, Rashed MS, Meyer B, Troelsen J, Peltonen L (2008) Independent introduction of two lactase-persistence alleles into human populations reflects different history of adaptation to milk culture. Am J Hum Genet 82: 57-72.

Heyman MB (2006) Lactose intolerance in infants, children, and adolescents. Pediatrics 118: 1279-1286.

Hollox EJ, Poulter M, Zvarik M, Ferak V, Krause A, Jenkins T, Saha N, Kozlov AI, Swallow DM (2001) Lactase haplotype diversity in the Old World. Am J Hum Genet 68: 160-172.

Ingram CJ, Mulcare CA, Itan Y, Thomas MG, Swallow DM (2009) Lactose digestion and the evolutionary genetics of lactase persistence. Hum Genet 124: 579-591.

Järvelä I, Enattah NS, Kokkonen J, Varilo T, Savilahti E, Peltonen L (1998) Assignment of the locus for congenital lactase deficiency to $2 \mathrm{q} 21$, in the vicinity of but separate from the lactase-phlorizin hydrolase gene. American Journal of Human Genetics 63: 1078-1085.

Jussila J, Isokoski M, Launiala K (1970) Prevalence of lactose malabsorption in a Finnish rural population. Scan J Gastroenterol 5: 49-56.

Krawczyk M, Wolska M, Schwartz S, Gruenhage F, Terjung B, Portincasa P, Sauerbruch T, Lammert F (2008) Concordance of genetic and breath tests for lactose intolerance in a tertiary referral centre. $J$ Gastrointestin Liver Dis 17: 135-139.

Kwiecień J, Szadkowski L, Szostak W, Żabka A, Karczewska K, Kasner J (2005) Hypolactasia in school children in Zabrze city. Pediatria Wspótczesna 7: 15-18.

Lisowska A, Wójtowicz J, Walkowiak J (2009) Small intestine bacterial overgrowth is frequent in cystic fibrosis: combined hydrogen and methane measurements are required for its detection. Acta Biochim Pol 56: 631-634.

Mądry E, Fidler E, Walkowiak J (2010) Lactose intolerance - current state of knowledge. Acta SciPol, Technol Aliment 9: 343-350.

Newcomer AD, McGill DB (1966) Distribution of disaccharidase activity in the small bowel of normal and lactase-deficient subjects. Gastroenterology 51: 481-488.
Rasinperä H, Savilahti E, Enattah NS, Kuokkanen M, Tötterman N, Lindahl H, Järvelä I, Kolho KL (2004) A genetic test which can be used to diagnose adult-type hypolactasia in children. Gut 53: 1571-1576.

Sahi T, Launiala K (1978) Manifestation and occurrence of selective adult-type lactose malabsorption in Finnish teenagers. A follow-up study. Am J Dig Dis 23: 699-704.

Savaiano DA, Boushey CJ, McCabe GP (2006) Lactose intolerance symptoms assessed by meta-analysis: a grain of truth that leads to exaggeration. J Nutr 136: 1107-1113.

Scrimshaw NS, Murray EB (1988a) The acceptability of milk and milk products in populations with a high prevalence of lactose intolerance. Am J Clin Nutr 48: 1079-1159.

Scrimshaw NS, Murray EB (1988b) Prevalence of lactose maldigestion. Am J Clin Nutr 48: 1086-1098.

Semenza G, Auricchio S, Mantei N (2001) Small-intestinal disaccharidases. In: The metabolic and molecular basis of inherited disease. Scriver CR, Beaudet al, Sly D, Valle D, eds, pp 1623-1650. McGraw-Hill, New York.

Socha J, Ksiazyk J, Flatz G, Flatz SD (1984) Prevalence of primary adult lactose malabsorption in Poland. Ann Hum Biol 11: 311-316.

Strocchi A, Corazza G, Ellis CJ, Gasbarrini G, Levitt MD (1993) Detection of malabsorption of low doses of carbohydrate: accuracy of various breath H2 criteria. Gastroenterology 105: 1404-1410.

Suarez FL, Savaiano DA (1994) Lactose digestion and tolerance in adult and elderly Asian-Americans. Am J Clin Nutr 59: 1021-1024.

Swallow DM (2003) Genetics of lactase persistence and lactose intolerance. Annu Rev Genet 37: 197-219.

Vesa TH, Korpela RA, Sahi T (1996) Tolerance to small amounts of lactose in lactose maldigesters. Am J Clin Nutr 64: 197-201.

Wang Y, Harvey CB, Pratt WS, Sams VR, Sarner M, Rossi M, Auricchio S, Swallow DM (1995) The lactase persistence/non-persistence polymorphism is controlled by a cis-acting element. Hum Mol Genet 4: 657-662.

Welsh JD, Poley JR, Bhatia M, Stevenson DE (1978) Intestinal disaccharidase activities in relation to age, race and mucosal damage. Gastroenterology 75: 847-855. 